\title{
Single-step Preparation of Nano-homogeneous NiO/YSZ Composite Anode for Solid Oxide Fuel Cells
}

\author{
Jung-Hoon Song ${ }^{1}$, Mi Young Park², Hye Won Park², Hyung-Tae Lim²,*
}

(Received 18 March 2013; accepted 6 May 2013; published online 15 May 2013)

\begin{abstract}
Homogeneous co-precipitation and hydrothermal treatment were used to prepare nano- and highly dispersed NiO/YSZ (yttria-stabilized zirconia) composite powders. Composite powders of size less than 100 $\mathrm{nm}$ were successfully prepared. This process did not require separate sintering of the YSZ and NiO to be used as the raw materials for solid oxide fuel cells. The performance of a cell fabricated using the new powders (max. power density $\sim 0.87 \mathrm{~W} / \mathrm{cm}^{2}$ ) was higher than that of a cell fabricated using conventional powders (max. power density $\sim 0.73 \mathrm{~W} / \mathrm{cm}^{2}$ ). Co-precipitation and hydrothermal treatment proved to be very effective processes for reducing cell production costs as well as improving cell performance.
\end{abstract}

Keywords: Fuel cells; Powder processing; Electrochemistry; Hydrothermal process; NiO/YSZ composite anode

Citation: Jung-Hoon Song, Mi Young Park, Hye Won Park and Hyung-Tae Lim, "Single-step Preparation of Nano-homogeneous NiO/YSZ Composite Anode for Solid Oxide Fuel Cells", Nano-Micro Lett. 5(2), 111-116 (2013). http://dx.doi.org/10.5101/nml.v5i2.p111-116

\section{Introduction}

Solid oxide fuel cells (SOFCs) are emerging electrochemical energy conversion devices, applicable to small systems of a few watts up to megawatt-sized power plants, with high efficiency and low emissions of pollutants. The SOFC system is generally operated at a temperature between 700 and $800^{\circ} \mathrm{C}$. Planar SOFCs are generally classified based on three types of structures, i.e., anode supported, cathode supported, and electrolyte supported. Among these cell structures, anode-supported cells are now recognized as the most desirable in terms of mechanical strength and cell performance. Figure 1 shows a schematic diagram of an anode-supported SOFC. As shown in Fig. 1, the anode support acts as the mechanical layer of the SOFC and the anode acts as the electrochemical reaction layer.
The most important factor in improving the cell performance is therefore controlling the microstructure of the anode. The microstructure of the anode affects gas transport as well as the electrochemical reactions. For these reasons, considerable effort has been made to control the anode microstructure precisely. A fine anode structure with a uniform arrangement of $\mathrm{Ni}$, YSZ (yttria-stabilized zirconia), and a porous phase is known to increase the electrochemical reactivity as well as the connectivity of the porous electrode. It is widely accepted that the preparation of $\mathrm{NiO} / \mathrm{YSZ}$ composite powders is an effective way of generating better anode microstructures [1-3]. Various preparation methods such as spray pyrolysis, mechanical milling, and gel combustion have been studied for producing composite powders [4-10]. However, these processes have the disadvantage of high production costs.

\footnotetext{
${ }^{1}$ Research Institute of Industrial Science and Technology (RIST), Fuel Cell Project, \#32 Hyoja-Dong, Nam-Gu, Pohang City, Gyeongbuk 790-330, Republic of Korea

${ }^{2}$ Changwon National University, School of Nano \& Advanced Materials Engineering, Changwon, Gyeongnam 641-773, Republic of Korea *Corresponding author. E-mail: htaelim@changwon.ac.kr
} 


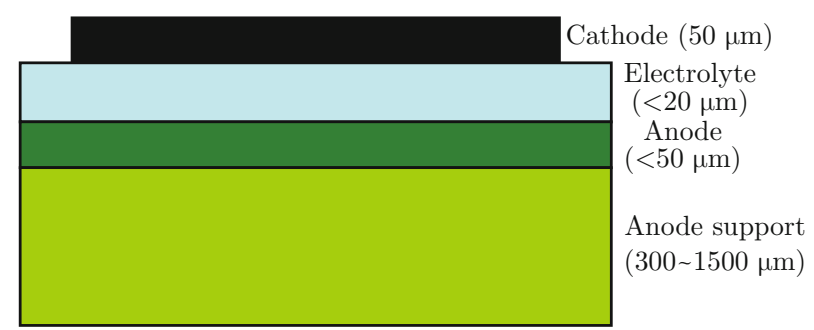

Fig. 1 Structure of typical anode-supported SOFC.

In this study, we prepared $\mathrm{NiO} / \mathrm{YSZ}$ composites using homogeneous co-precipitation and hydrothermal treatment. This process for the preparation of $\mathrm{NiO} / \mathrm{YSZ}$ composites is low cost because no sintering process is required. Also, the powders prepared using this process are expected to improve the cell performance because they can generate well-organized TPB (three phase boundary) as well as giving effective connectivity of the Ni. In comparison with the previous study by Sato et al. [4], we tried two kinds of precipitator, $\mathrm{NH}_{3}$ and $\mathrm{NaOH}$ to investigate their effects on microstructures of $\mathrm{NiO} / \mathrm{YSZ}$ powder. In addition, we fabricated anode supported cells (the most practical type for commercialization) utilizing our $\mathrm{NiO} / \mathrm{YSZ}$ nano-composite powder as an anode functional layer, and showed its superior electrochemical properties with measuring I-V characteristics as well as impedance spectra.

\section{Experimental}

\section{Co-precipitation with various precipitators}

To select the best the precipitator, several precipitation tests were conducted. Zirconyl oxychloride octahydrate $\left(\mathrm{ZrOCl}_{2} \cdot 8 \mathrm{H}_{2} \mathrm{O}\right)$, yttrium chloride hexahydrate $\left(\mathrm{YCl}_{3} \cdot 6 \mathrm{H}_{2} \mathrm{O}\right)$, and nickel chloride hexahydrate $\left(\mathrm{NiCl}_{2} \cdot 6 \mathrm{H}_{2} \mathrm{O}\right)$ were used as starting materials. These were dissolved in deionized water to prepare source solutions with total cation concentrations of $0.02 \mathrm{M}$. The source solution was precipitated with various precipitators, i.e., sodium hydroxide $(\mathrm{NaOH})$, ammonia $\left(\mathrm{NH}_{3}\right)$, urea $\left(\left(\mathrm{NH}_{2}\right)_{2} \mathrm{CO}\right.$, and ammonium bicarbonate $\left(\mathrm{NH}_{4} \mathrm{HCO}_{3}\right)$. The precipitation was conducted at $\mathrm{pH}=5.0-10.0$. After precipitation was complete, the supernatant was analyzed using inductively coupled plasma (ICP) spectroscopy to measure the concentration of unreacted metal ions.

\section{Preparation of $\mathrm{NiO} / \mathrm{YSZ}$ composite by $\mathrm{NH}_{3}$ precipitation}

The effect of $\mathrm{NH}_{3}$ on the preparation of $\mathrm{NiO} / \mathrm{YSZ}$ was investigated to understand the metal hydroxide precipitation mechanism. Using $\mathrm{NH}_{3}$ as the precipi- tator has the advantage that a delicate cleaning process is not required. This is because $\mathrm{NH}_{3}$ is decomposed into $\mathrm{N}_{2}$ and $\mathrm{H}_{2} \mathrm{O}$ during calcinations. Similar to the co-precipitation test, total cation concentration of source solution was $0.02 \mathrm{M}$. The $\mathrm{NH}_{3}$ solution was added dropwise to the concentrated source solution to induce precipitation. The precipitation was conducted at $\mathrm{pH}=2.0-10.0$. The solution containing the precipitate was hydrothermally treated for $72 \mathrm{~h}$ at $180^{\circ} \mathrm{C}$.

\section{Preparation of $\mathrm{NiO} / \mathrm{YSZ}$ composite by $\mathrm{NaOH}$ precipitation}

To overcome the problems caused by the $\mathrm{NH}_{3}$ precipitator, such as difficulties in controlling the $\mathrm{pH}$ and adjusting the concentration, $\mathrm{NaOH}$ was used as the precipitator. This has the disadvantage that a delicate cleaning process is required. As in the co-precipitation tests, the concentration of cations in the source solution was $0.02 \mathrm{M}$. The source solution was added to a $0.5 \mathrm{M} \mathrm{NaOH}$ solution to induce precipitation. The precipitation was conducted at $\mathrm{pH}=7.5-10.0$. The solution after precipitation was hydrothermally treated for $48 \mathrm{~h}$ at $130^{\circ} \mathrm{C}$.

\section{SOFC fabrication and testing}

The powders prepared in this study were tested as the anode materials in SOFCs. To achieve this goal, SOFCs were fabricated using two different anode powders. One powder was a conventional anode powder fabricated from NiO (J. T. Baker, UK) and YSZ (TZ8Y, Tosho, Japan), and the other was a composite powder synthesized by the present process. The only difference between the two cells was the powder morphologies. The anode-supported electrolyte was fabricated using a tape-casting and co-firing process. More detailed information on the fabrication process is available in the literature [11, 12]. After fabrication of the anode-supported electrolyte, a La-Sr-Co-Fe- $\mathrm{O}_{3}$ cathode was screen printed on the electrolyte layer at a thickness of about $50 \mu \mathrm{m}$; it was then fired at $1040^{\circ} \mathrm{C}$ for $3 \mathrm{~h}$. The current-voltage characteristics ( $I-V$ curve) and impedance spectra were measured using a Solartron $1260 / 1287$ electrochemical system (AC and DC) in order to compare the electrochemical performances of the cells. These measurements were conducted at $750^{\circ} \mathrm{C}$ with fuel gas in $300 \mathrm{sccm}$ of $97 \% \mathrm{H}_{2}-3 \% \mathrm{H}_{2} \mathrm{O}$ and oxidant gas in $1000 \mathrm{sccm}$ of air. The impedance measurements were conducted in the frequency range $\sim 0.1-100$ $\mathrm{kHz}$ with a signal amplitude of $100 \mathrm{mV}$ under opencircuit conditions. A detailed description of the celltesting procedure and method can be found elsewhere [13]. 


\section{Results and Discussion}

\section{Selection of precipitator}

Table 1 shows the degree of precipitation of the metal hydroxides (yield) obtained with different precipitators. As shown in Table $1, \mathrm{Zr}(\mathrm{OH})_{4}$ was generated in high yield, irrespective of the precipitator. However, the yield of $\mathrm{Ni}(\mathrm{OH})_{2}$ was highly affected by the type of precipitator. It can be seen that $\mathrm{NaOH}$ and $\mathrm{NH}_{3}$ generated metal hydroxides effectively, with high yields of over $90 \%$. These precipitators were therefore selected for the preparation of the $\mathrm{NiO} / \mathrm{YSZ}$ composites; the results are discussed in detail later.

Table 1 Maximum yields of metal hydroxides obtained with different precipitators

\begin{tabular}{cccc}
\hline Precipitator & $\begin{array}{c}\mathrm{pH} \text { for maximum } \\
\text { precipitation }\end{array}$ & $\mathrm{Zr}(\mathrm{OH})_{4}$ & $\mathrm{Ni}(\mathrm{OH})_{2}$ \\
\hline $\mathrm{NaOH}$ & $>10$ & $\odot$ & $\odot$ \\
$\mathrm{NH}_{3}$ & $>8.5$ & $\odot$ & $\bigcirc$ \\
$\left(\mathrm{NH}_{3}\right) \mathrm{HCO}_{3}$ & 5.7 & $\odot$ & $\Delta$ \\
$\left(\mathrm{NH}_{2}\right)_{2} \mathrm{CO}$ & 7.4 & $\odot$ & $\mathrm{X}$ \\
\hline
\end{tabular}

Yield: ๑: $99 \%$; $\bigcirc$ : over $90 \%$; $\Delta$ : over $70 \%$; X: less than $50 \%$.

\section{Preparation of $\mathrm{NiO} / \mathrm{YSZ}$ with $\mathrm{NH}_{3}$ precipitator}

The advantage of $\mathrm{NH}_{3}$ as the precipitator is that a delicate cleaning process is not required. As shown in Table $1, \mathrm{NH}_{3}$ was verified to be a good precipitator of $\mathrm{Ni}(\mathrm{OH})_{2}$ and $\mathrm{Zr}(\mathrm{OH})_{4}$, giving high yields of metal hydroxides. Two influencing parameters, i.e., pH and concentration, were controlled in this study.

Figure 2 shows the results of ICP analysis and the effect of $\mathrm{pH}$ on the yields of $\mathrm{Y}^{3+}, \mathrm{Zr}^{4+}$, and $\mathrm{Ni}^{2+}$ in the generation of $\mathrm{NiO} / \mathrm{YSZ}$ composites. It was measured by analyzing the supernatant of the product solution after the hydrothermal treatment. As shown in Fig. 2, YSZ was generated above $\mathrm{pH}=5$ because the reaction extents of $\mathrm{Y}^{3+}$ and $\mathrm{Zr}^{4+}$ were close to $100 \%$ above this $\mathrm{pH}$ value. However, it was not possible to obtain complete reaction of $\mathrm{Ni}^{2+}$ at all $\mathrm{pH}$ values. The maximum reaction extent $(\sim 95 \%)$ was obtained only at $\mathrm{pH}=8.5$. Above and below this $\mathrm{pH}$ value, the reaction extent decreased rapidly. Figure 2 also indicates that the precursor concentration affects the reaction extent. The extent of the reaction of $\mathrm{Ni}^{2+}$ decreased, as shown in Fig. 2, when a solution of high-concentration, e.g., 0.05 $\mathrm{M}$, was used. The reaction extent decreased with increasing concentration of source solution. The above findings show that the yield is affected by both factors, i.e., solution $\mathrm{pH}$ and concentration. We therefore analyzed the competitive balances based on the solution chemistry. Deng et al. studied the competitive balance of $\mathrm{Ni}^{2+}$ and $\mathrm{Ni}(\mathrm{OH})_{2}$ in the presence of $\mathrm{NH}_{3}$ or $\mathrm{NH}_{4}^{+}$ ions [14]. Equation (1) shows the calculated equilibrium constant based on their study.

$$
\begin{aligned}
& \mathrm{Ni}(\mathrm{OH})_{2}(\mathrm{~s})+6 \mathrm{NH}_{3}=\mathrm{Ni}\left(\mathrm{NH}_{3}\right)_{6}^{2+}+2 \mathrm{OH}^{-} \\
& K=2.2 \times 10^{-7}
\end{aligned}
$$

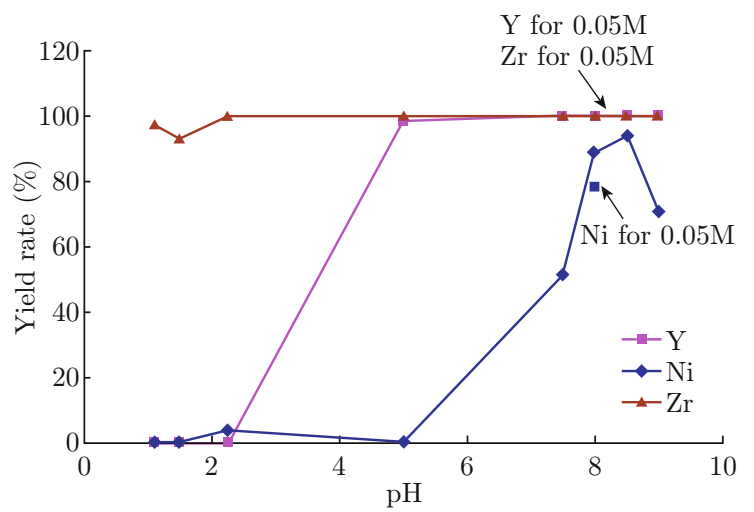

Fig. 2 Results of ICP analysis: effect of $\mathrm{pH}$ and concentration on yield.

This indicates that $\mathrm{Ni}(\mathrm{OH})_{2}$ can form complexes with excess free $\mathrm{NH}_{3}$. They also showed that the complexing acid/alkali competition balance can be expressed as follows [2],

$$
\begin{aligned}
& \mathrm{Ni}(\mathrm{OH})_{2}(\mathrm{~s})+6 \mathrm{H}_{2} \mathrm{O}+2 \mathrm{NH}_{4}^{+}= \\
& \quad \mathrm{Ni}\left(\mathrm{NH}_{3}\right)_{6}^{2+}+2 \mathrm{NH}_{3} \cdot \mathrm{H}_{2} \mathrm{O} \\
& K=6.8 \times 10^{2}
\end{aligned}
$$

The equilibrium constant in equation (2) is quite large. The solubility of $\mathrm{Ni}(\mathrm{OH})_{2}$ is therefore greatly influenced by the presence of $\mathrm{NH}_{4}^{+}$. This also indicates that complete conversion of $\mathrm{Ni}^{2+}$ into $\mathrm{Ni}(\mathrm{OH})_{2}$ is impossible. Figure 3 shows the competitive balances of $\mathrm{Ni}^{2+}+\mathrm{NH}_{3} \mathrm{H}_{2} \mathrm{O}$ based on the study by Deng et al. [14]. From the diagram, it can be seen that the region in which $\mathrm{Ni}(\mathrm{OH})_{2}$ exists, i.e., region $\mathrm{I}$, is very narrow (from $\mathrm{pH} 7.6 \sim 8.1$ for $0.02 \mathrm{M} \mathrm{Ni}^{2+}$ solution). Furthermore, this region becomes narrower with increasing $\mathrm{Ni}^{2+}$ concentration. The competitive balance could explain why the maximum yield was obtained at $\mathrm{pH}=8.5$ and the reaction decreased with increasing $\mathrm{Ni}^{2+}$ concentration, as shown in Fig. 2. The above investigation shows that the preparation of $\mathrm{NiO} / \mathrm{YSZ}$ using $\mathrm{NH}_{3}$ is unsatisfactory. To use both region I and region II in Fig. 3, the precipitator should not contain $\mathrm{NH}_{3}$-based ions. $\mathrm{NaOH}$ was therefore used as the precipitator; this will be discussed in the next section.

Figure 4 shows scanning electron microscopy (SEM) images of $\mathrm{NiO} / \mathrm{YSZ}$ composites prepared at $\mathrm{pH}=8.5$ with $\mathrm{NH}_{3}$ as the precipitator. As shown in Fig. 4, two types of particle are observed: very large particles and very small particles. The large particles were several microns in size and globular. In contrast, the small particles were of size about $20 \mathrm{~nm}$. To understand the powder compositions, EDS analysis was conducted. It 


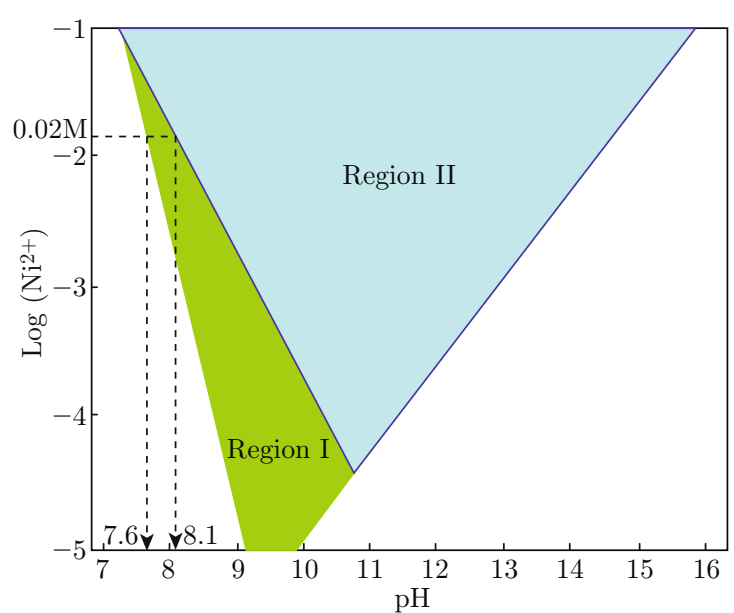

Fig. 3 Competitive balance in reaction of $\mathrm{Ni}^{2+}+\mathrm{NH}_{3} \mathrm{H}_{2} \mathrm{O}$ (10).

showed that the large particles were mainly composed of $\mathrm{NiO}$, and small particles of YSZ. Deng et al. studied the effect of the zeta potential on $\mathrm{NiO}$ size. They found that the agglomerate size is the biggest near the iso-electric point of $\mathrm{NiO}$. This value is located close to $\mathrm{pH}=10.59$. In our results, the powder sizes obtained by SEM analysis were several microns in size, irrespective of the $\mathrm{pH}$ value, and they are too large to determine the effect of surface charge. However, we found that the powder obtained near $\mathrm{pH}=10$ was easier to filter than the powders obtained at other $\mathrm{pH}$ values during the cleaning process. This may indicate that the particle sizes are affected by the surface charges of the particles. This indirectly implies that the sizes of the particles can be optimized by the preparation procedure.

\section{Preparation of NiO/YSZ nanocomposites}

The above results verified that $\mathrm{NH}_{3}$ was not an effective precipitator for obtaining high yields of metal hydroxides. They also showed that complete precipitation of $\mathrm{Ni}(\mathrm{OH})_{2}$ was not possible because of competitive balances. A different precipitator, $\mathrm{NaOH}$, was therefore used. Sato et al. studied $\mathrm{NaOH}$ as a precipitator in the preparation of NiO/YSZ composites [4]. Their analysis suggested that it is possible to precipitate all the metal hydroxide over a broad $\mathrm{pH}$ range. Figure 5 shows the microstructures of $\mathrm{NiO} / \mathrm{YSZ}$ composite particles prepared using $\mathrm{NaOH}$ as the precipitator. Figure 5 shows that a NiO/YSZ composite of size less than $200 \mathrm{~nm}$ was successfully prepared, irrespective of the solution $\mathrm{pH}$. Also, it is expected that smaller nanoparticles can be obtained at high $\mathrm{pH}$ values such as $\mathrm{pH}=13$ because $\mathrm{NiO}$ has a high negative zeta potential at that point. Sato et al. suggested that high $\mathrm{pH}$ values affect the preparation of $\mathrm{NiO} / \mathrm{YSZ}$ as follows [4].

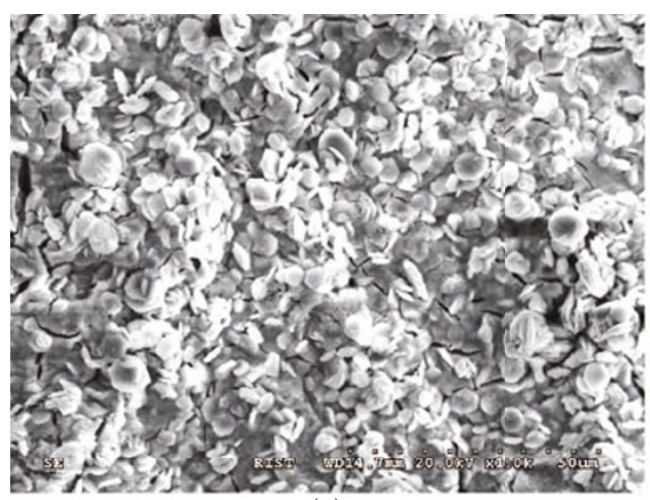

(a)

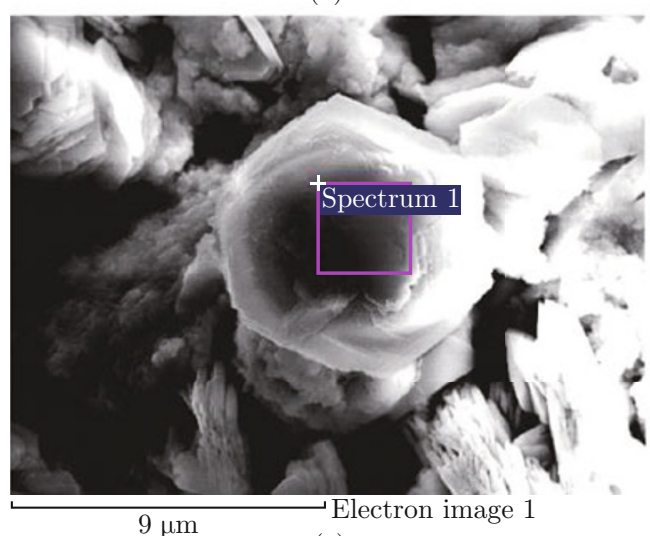

(c)

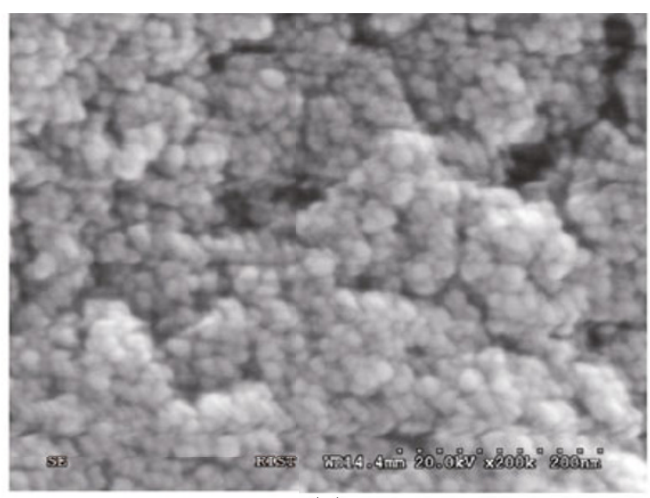

(b)

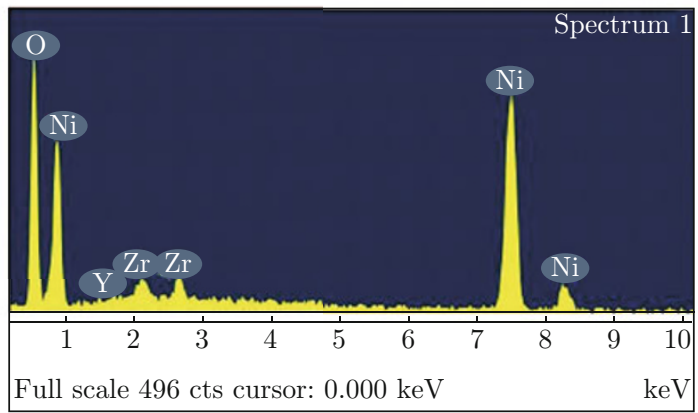

(d)

Fig. 4 SEM images of $\mathrm{NiO} / \mathrm{YSZ}$ composite powders synthesized with $\mathrm{NH}_{3}$ precipitator (a) $1000 \times$, (b) $200 \mathrm{000 \times}$ and (c) $7000 \times$. 


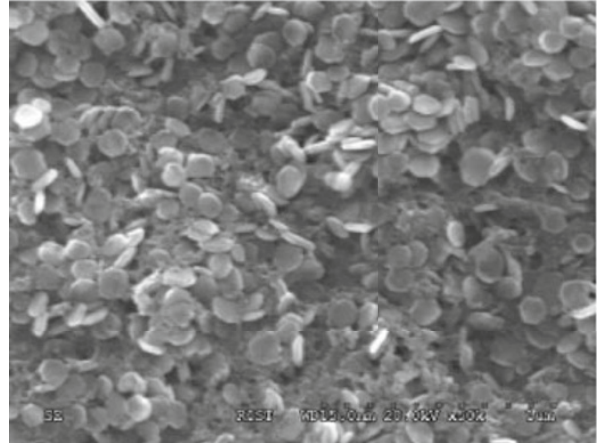

(a)

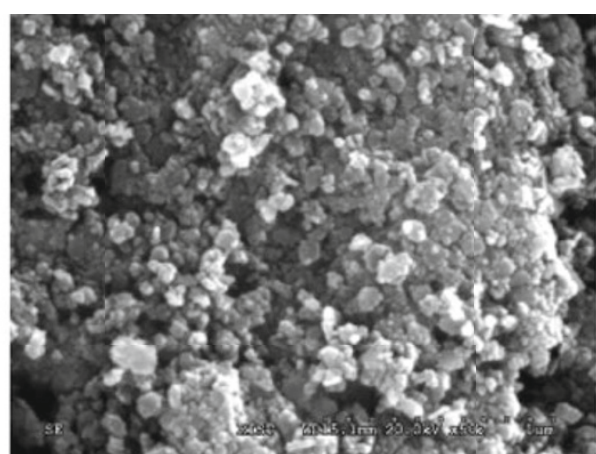

(b)

Fig. 5 Microstructures of $\mathrm{NiO} / \mathrm{YSZ}$ synthesized with $\mathrm{NaOH}$ precipitator at (a) $\mathrm{pH}=9$ and (b) $\mathrm{pH}=13$.

1. The precipitate size decreases, because the number density of nuclei increases.

2. The differences among hydroxide precipitation extents decrease.

3. Ostwald ripening is suppressed because a higher $\mathrm{pH}$ can stabilize finer precipitates and prevent dissolution.

Finer hydroxide phases with a more uniform distribution can therefore be obtained at $\mathrm{pH}=13$ than at lower $\mathrm{pH}$ values. Uniformly distributed $\mathrm{NiO}$ and $\mathrm{YSZ}$ phases suppress grain growth of each other during the subsequent calcination step, resulting in successful synthesis of nanosized $\mathrm{NiO}(\sim 50 \mathrm{~nm}) / \mathrm{YSZ}(\sim 5 \mathrm{~nm})$ composite particles.

\section{Electrochemical testing}

Figure 6 shows the current-voltage characteristics ( $I-V$ curves) of button cells fabricated using commercial $\mathrm{NiO} / \mathrm{YSZ}$ composite powder and a nano-YSZ/NiO composite powder prepared using our new method. The new powder showed a better electrochemical performance than the conventional powder. The maximum power density of the cell fabricated using the new powders was $\sim 0.87 \mathrm{~W} / \mathrm{cm}^{2}$ while that of a cell fabricated using conventional powders was $\sim 0.73 \mathrm{~W} / \mathrm{cm}^{2}$. This may be caused by increased TPBs as a result of the homogeneous and nanosized NiO/YSZ composite anode. Figure 7 compares the impedance spectra between cells with nanocomposite anode and conventional anode; the first semi-circle (corresponding to frequency range $10 \sim 10 \mathrm{kHz}$ ) significantly decreased in the case of nanocomposite anode. One of the authors in the present work found that this impedance frequency range also responds to the changes of anode composition [15]. Thus, it can be said that the first semi-circle is dominated by activation polarization of anode and the improved electrochemical performance in Fig. 7 is mainly attributed to a reduction in the activation polarization resistance of the anode. Also, a slight decrease in ohmic resistance (the high frequency intercept of the impedance spectra on the real axis) is due to the

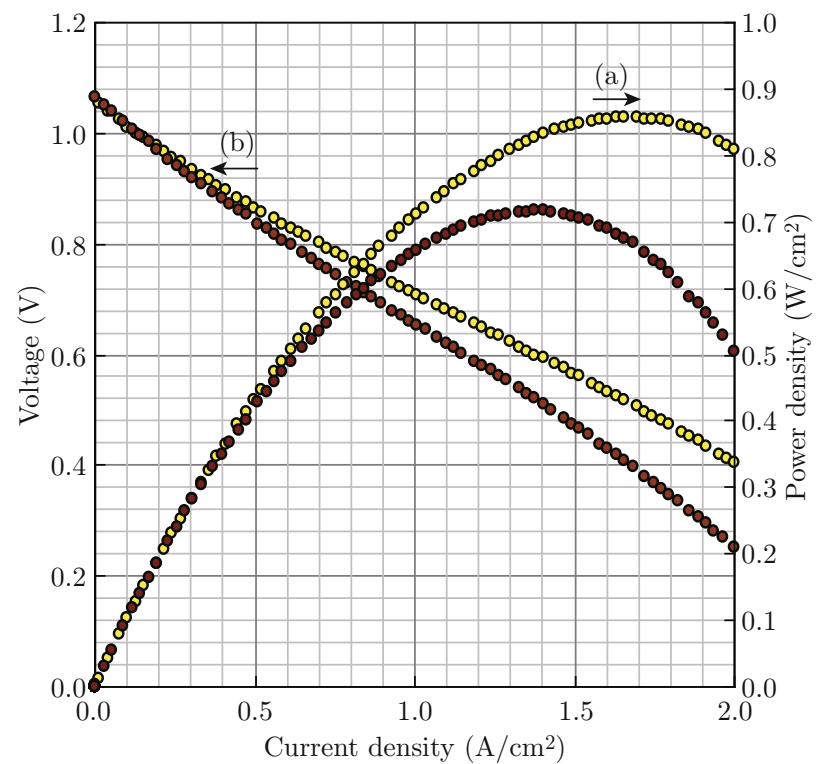

Fig. 6 Current-voltage characteristics of button cells fabricated with (a) nanocomposite anode and (b) conventional anode $750^{\circ} \mathrm{C}$.

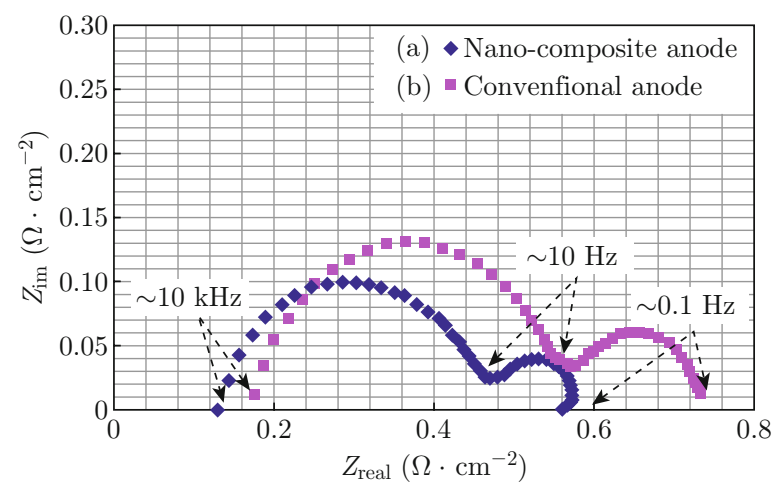

Fig. 7 Impedance spectra measured under open-circuit conditions at $750^{\circ} \mathrm{C}$ (a) cell with nanocomposite anode and (b) cell with conventional anode.

well-structured connectivity of the $\mathrm{NiO} / \mathrm{YSZ}$ in the anode layer. The results show that the present process is very effective and promising for the preparation of nanodispersed $\mathrm{NiO} /$ YSZ powders, and, eventually, high- 
performance SOFCs.

\section{Conclusion}

We successfully synthesized nanosized $\mathrm{NiO} / \mathrm{YSZ}$ composite powders via co-precipitation and hydrothermal treatment. A basic study of $\mathrm{NiO} / \mathrm{YSZ}$ powder preparation was conducted using different precipitators. A general hydrothermal method using $\mathrm{NH}_{3}$ as the precipitator was not suitable for $\mathrm{NiO} / \mathrm{YSZ}$ composite production because of the competitive balance of $\mathrm{Ni}^{2+}$ with $\mathrm{NH}_{3}$. Agglomeration of the $\mathrm{NiO}$ powders was mainly affected by the iso-electric point of $\mathrm{NiO}$. This can be controlled by changing the $\mathrm{pH}$ and the precipitation procedure. A different precipitator, $\mathrm{NaOH}$, was used, and the synthesized $\mathrm{NiO} / \mathrm{YSZ}$ composites had particles sizes of $\sim 50 \mathrm{~nm}$. Electrochemical testing of a cell fabricated form powders produced using the present process showed that the cell performance was much better than that of a cell produced from conventional powders. This may be caused by an increment in the TPB length and well-structured connectivity of the $\mathrm{NiO} / \mathrm{YSZ}$ in the anode layer.

\section{Acknowledgments}

This research was supported by Basic Science Research Program through the National Research Foundation of Korea (NRF) funded by the Ministry of Education, Science and Technology (2012R1A1A1013782) and a fostering project funded by the Ministry of Education, Science and Technology (MEST).

\section{References}

[1] S.-D. Kim, H. Moon, S.-H. Hyun, J. Moon, J. Kim and H.-W. Lee, "Performance and durability of Ni-coated YSZ anodes for intermediate temperature solid oxide fuel cells", Solid State Ionics 177(9-10), 931-938 (2006). http://dx.doi.org/10.1016/j.ssi.2006.02.007

[2] S.-D. Kim, H. Moon, S.-H. Hyun, J. Moon, J. Kim and H.-W. Lee, "Nano-composite materials for highperformance and durability of solid oxide fuel cells", J. Power Sources 163(1), 392-397 (2006). http://dx . doi.org/10.1016/j.jpowsour. 2006.09.015

[3] D. Yoon, J.-J. Lee, H.-G. Park and S.-H. Hyun, "NiO/YSZ-YSZ nanocomposite functional layer for high performance solid oxide fuel cell anodes", J. Electrochem. Soc. 157(4), B455-B462 (2010). http://dx. doi.org/10.1149/1.3294768

[4] K. Sato, G. Okamoto, M. Naito and H. Abe, "NiO/YSZ nanocomposite particles synthesized via co-precipitation method for electrochemically active Ni/YSZ anode", J. Power Sources 193(1), 185-188 (2009). http://dx.doi.org/10.1016/j.jpowsour . 2008.12 .038
[5] T. Fukui, S. Ohara, M. Naito and K. Nogi, "Morphology control of Ni-YSZ cermet anode for lower temperature operation of SOFCs", J. Power Sources 125(1), 17-21 (2004). http://dx.doi.org/10.1016/ S0378-7753(03) 00817-6

[6] T. Fukui, K. Murata, S. Ohara, H. Abe, M. Naito and K. Nogi, "Morphology control of Ni-YSZ cermet anode for lower temperature operation of SOFCs", J. Power Sources 125(1), 17-21 (2004). http://dx.doi.org/10. 1016/S0378-7753(03)00817-6

[7] G. Chao, H. Cai and J. Xie, "Preparation of nanocomposite Ni/YSZ cermet powder by EDTA complexes-gel conversion process", Mater. Lett. 57(21), 3287-3290 (2003). http://dx.doi.org/10. 1016/S0167-577X (03) 00049-1

[8] M. Marinsek, K. Zupan and J. Macek, "Preparation of Ni-YSZ composite materials for solid oxide fuel cell anodes by the gel-precipitation method", J. Power Sources 86(1-2), 383-389 (2000). http://dx.doi.org/ 10.1016/S0378-7753(99)00425-5

[9] T. Priyatham and R. Bauri, "Synthesis and characterization of nanocrystalline Ni-YSZ cermet anode for SOFC", Mater. Charact. 61(1), 54-58 (2010). http: // dx.doi.org/10.1016/j.matchar. 2009.10.005

[10] K. Chen, Z. Lu, Z. Chen, N. Ai, X. Huang, B. Wei, J. $\mathrm{Hu}$ and $\mathrm{W} . \mathrm{Su}$, "Characteristics of NiO-YSZ anode based on $\mathrm{NiO}$ particles synthesized by the precipitation method", J. Alloy Comp. 454(1-2), 447453 (2008). http://dx.doi.org/10.1016/j.jallcom. 2006.12 .130

[11] J.-H. Song, N. M. Sammes, S.-II Park, S. Boo, H.-S. Kim, H. Moon and S.-H. Hyun, "Fabrication and characterization of anode-supported planar solid oxide fuel cell manufactured by a tape casting process", J. Fuel Cell Sci. Tech. 5(2), 021003-021008 (2010). http:// $\mathrm{dx}$.doi.org/10.1115/1.2885401

[12] J.-H. Song, S.-II. Park, J.-H. Lee and H.-S. Kim, "Fabrication characteristics of an anode-supported thin-film electrolyte fabricated by the tape casting method for IT-SOFC", J. Mat. Process. Tech. 198(13), 414-418 (2008). http://dx.doi.org/10.1016/j. jmatprotec. 2007.07.030

[13] Y. M. Park, H. J. Lee, H. Y. Bae, J. S. Ahn and H. Kim, "Effect of anode thickness on impedance response of anode-supported solid oxide fuel cells", Int. J. Hydrogen Energy 37(5), 4394-4400 (2012). http://dx. doi.org/10.1016/j.ijhydene. 2011.11.152

[14] X. Y. Deng and Z. Chen, "Preparation of nano$\mathrm{NiO}$ by ammonia precipitation and reaction in solution and competitive balance", Mater. Lett. 58(34), 276-280 (2004). http://dx.doi.org/10.1016/ S0167-577X (03) 00469-5

[15] H.-T. Lim, S. Hwang, Y. Park and I. Lee, "Performance and long term stability of large area anode supported solid oxide fuel cells (SOFCs)", Solid State Ionics 225(4), 124-130 (2012). http://dx.doi.org/10. 1016/j.ssi.2012.03.023 